\title{
Health Profile of School Age Children Using Digital Technology in Beni-Suef City
}

\author{
SAFAA S. MUSTAFA, M.Sc.*; EBTESAM M. EL-SAYED, D.N.Sc.** and SANEYA M. RISK, D.N.Sc.** \\ The Department of Community Health Nursing, Faculty of Nursing, Beni-Suef* and Cairo** Universities
}

\begin{abstract}
Background: Digital technology assumed central roles in elementary school aged childrens daily lives. Today, children have access to all types of digital technology and exceeding recommended screen time allowed for their age. Recent evidence raises concern about consequences of digital technology on children bio psychosocial health profile.
\end{abstract}

Aim of Study: This study aimed to assess bio-psychosocial health profile of school age children (9-15 yrs old) using digital technology in Beni-Suef City. A descriptive research design was utilized.

Subjects and Methods: Setting the study was conducted at four official experimental schools in Beni-Suef City. A systematic random sample of 240 elementary school students was selected. Two tools were used to collect data, the first tool includes 4 parts asking about demographic and personal data, child physical health profile, child psychosocial health profile, scholastic and sporting activities. Second tool, digital technology usage data includes 5 parts, digital technology ownership, preferable types, pattern, screen time and activities of digital technology used by students.

Results: Revealed that $52.5 \%$ of students aged from 12 15 years old, while $77.5 \%$ of them didn't participate in sporting activities. Additionally, revealed that students have complained of physical symptoms ranked gradually as digestive symptom, musculoskeletal symptoms, neurological symptoms, and ophthalmological symptoms $(93.3 \%, 83.75 \%, 81.25 \%$, $56.25 \%$ ) respectively. Moreover, $33.8 \%$ of them were overweight and $32.6 \%$ of them were obese. Additionally students have complained of psychosocial health problems ranked gradually as mild/moderate symptoms of aggressive behavior, anxiety behavior, and loneliness behavior and of ADHD behavior. $(61.5 \%, 37.9 \%, 36.6 \%, 30.8 \%)$ respectively. Furthermore, screen time among students was 6 to less than 10 hours per day among $48.3 \%$ of students. There was a highly statistical significance relationship between types of digital technology, screen time and bio-psycho-social health problems reported by elementary school students.

The study concluded that students aged between (9-15) years old have bio-psycho-social health problems due to misuse of digital technology usage and exceeded the recommended hours of screen time.

Correspondence to: Dr. Safaa S. Mustafa, The Department of Community Health Nursing, Faculty of Nursing, Beni-Suef University
Recommendations: It is recommended to raise awareness of, students, parents, teachers about negative effect of digital technology and assist parents to set rules for controlling screen time and content of digital technology.

Key Words: Health profile - School age - Digital - Technology.

\section{Introduction}

OUR nation's children are our greatest asset and our hope for the future. Moreover the stage of (615 ) yeas old is the childhood foundation for future life, which determined features of his character, through interconnectedness of the skills, or expertise, or values. School age children are undergoing periods of rapid growth and development and have high physical psychological and social needs. Child also needs to satisfy basic necessities, physical, psychological, mental, social and natural consequence of growth, development and basic necessities in life, until his growth become free from diseases, problems and setbacks [1-3]

According to Ghosh [2], school serves as the agent for transmitting the values of the society to each succeeding generation of children and as the setting for most of their relationship with peers. As a socializing agent second only to the family, schools exert a profound influence on the social development of children. Moreover children spend more time in school than in any other formal institutional structure. Also schools play a key part in children's development, from peer relationships and social interactions to academic attainment and cognitive progress, emotional control and behavioral expectations, and physical and moral development [4].

Today the world are in the midst of a technology revolution that is happening so fast we can barely keep up with the number of devices and the options for screen time available to children on computers, tablets, cell phones, iPhones, monitors, interactive 
"app" toys, and on and on which affect their growth and development in so many ways $[\mathbf{5 , 6}]$. Digital technology, including electronic devices and video games are the most innocent looking destroyer set on families technology overuse by children is the most imperative question of the 21 st century, and requires immediate attention and action (Rowan, 2014). Likewise handheld devices (cell phones, tablets, electronic games) have dramatically expanded the accessibility and utilization of technology, causing escalating usage, particularly in school age children [7]. Elementary aged children now use an average 7.5 hours per day entertainment technology, (TV, video games, internet, movies, and cell phones), with total amount of exposure time averaging 11 hours per day [8]. Dramatically Two thirds of children have reported that their parents do not restrict their access to technology, and $75 \%$ of these children have devices in their bedrooms [9]

As reported by [7,9-11], the positive impact of digital technology use includes fostering education and providing competition skills. While the negative impact of technology overuse includes a lot of biopsycho-social health problems such as physical health problems, including developmental delay, mental illnesses, digital dementia, obesity, diabetes, cardiovascular disorder, rapid brain growth, back pain, weak eye sight, myopia, movement deprivation, sensory overstimulation and touch deprivation. Psychosocial health problems include poor communication, aggression, antisocial relationship, and declining empathy. Furthermore, impact on academic performance include attention deficit illiteracy, poor academic performance and negative impact on writing skills, in addition radiation emission, sleep deprivation, and addiction.

American medical association, [12] also stated that, Childhood obesity has more than doubled in children in the past 30 years. Study of 10-12 years old children in seven European countries found that those who had television in their bed room and particularly those who watched more daily $\mathrm{TV}$, had increased BMI $[\mathbf{1 3 , 1 4 ]}$. In the same line study was conducted in Dar es Salaam City in Tanzania to assess the prevalence of overweight and obesity among primary school children aged 8-13 years, the prevalence of overweight and obesity was $15.9 \%$ and $6.7 \%$. The results of the study confirmed that one of the main causes of obesity was misuse of digital technology [15]

In the same [16] conducted a study on behavioral problems associated with using smart phones among children aged between (8-12 years old) in
K.S.A found that, most behavioral problems were the social, educational and psychological problems, aggressive (cyber bullying, cyber aggression) or sexual (pornography, sexting, stranger danger) in nature. An Egyptian study was also carried out to identify the prevalence and risk factors for aggression, violence and criminal behavior among children aged between 11-19 years old. Overall 26.9\% of children were assessed to be at high risk and $20.2 \%$ at extremely high risk of aggression and criminal behavior, also reported that one of the causes were misuse of digital technology among students [17]. Community Health Nurse (CHN) is in a unique position to educate families about both the complexities of the digital world and the challenging social and health issues that online experience cause. The role of CHN also include educating parents to work on their own participation gap in their homes by becoming better educated about the many technologies that their youngsters are using [18]

Significance of the study: The main results of a research conducted by GSMA and NTT DOCOMO Inc. on more than 3500 children in Japan, India, Egypt and Paraguay reported that mobile phone ownership by children aged 8 to 16 years, was almost $70 \%$ high in all four countries. Egypt has ranked the highest in using smart phones among school age children. In addition to that the uses of social networks on mobile phones were more common among children who use smart phones, where $85 \%$ use social networks from their smart phones in Egypt. Surprisingly, 70-80\% of parents are concerned about issues such as excessive use of mobile phones, raising costs, privacy and complain about not being able to control the number of hours children spend in front of digital technology [19].

Another comparative study by GSMA and NTT DOCOMO, Inc. was done in 2013 in four Arab countries, including Algeria, Egypt, Iraq and Saudi Arabia raveled that over than $80 \%$ of children aged between 10 and 12 years old were the most common ages to receive their first mobile phone, while $81 \%$ of children aged between 8-18 years old currently using mobile phone whereas one in three of them were owning smart phones. Both Saudi Arabia and Egypt has showed high usage rates from a younger age. However in Saudi Arabia 27\% of children who use mobile phones use the mobile to access the internet games in schools, followed by $15 \%$ of Algerian and 13\% of Egyptian children. Likewise $88 \%$ of parents has concerns about inappropriate use of digital technology among their children and negative effect of digital technology on them [20] 
Al-Hadlaq [21] held a study about advantages and disadvantages of digital technology use on school age children and motives of over using them from the viewpoints of public education students aged between (8-15 years old) in Saudi Arabia and indicated that negative effects of electronic media are numerous on children and are classified into religious, behavioral, physical effect on health, social harm, academy performance, security and safety, and falls under each category a number of negative effects.

It is worth saying that there is lacking of researches in nursing field in this area in Egypt, therefore this research will examine the bio-psychosocial health profile of children using digital technology and will identify the most important health problems that appear in children resulting from over using of these devices. The result of the current study will contribute in a positive way to assist parents, teachers, health professionals, government, researchers and technology production corporations to join together to manage the balance between healthy activity and technology use among school aged children, a concept termed balanced technology management. Therefore, the aim of this study was to assess bio-psycho-social health profile of school age children (9-15yrs old) using digital technology in Beni-Suef City.

\section{Subjects and Methods}

The study was conducted from March till June 2017.

Data was collected during the academic year (2016-2017) over a period of 4 months from (March 2017-June 2017) the fourth month was to collect the data from the parents.

Research questions: Q1- What is the biopsycho-social health profile of school age children using digital technology in Beni-Suef City?

Research design: A descriptive exploratory research design was utilized for this study.

Setting: The study was conducted at official experimental schools in Beni-Suef City. Total number of schools in directorate sector of BeniSuef City is nine schools. One school was selected randomly from each sector of the city (north, south, east, and west), namely Alshrook, Alnahda, Ali Mubarak, Paroot official experimental schools in (2016-2017).

Sample: Schools was randomly selected from official experimental schools in Beni-Suef City according to four directorate sectors (north, south, east, and west), then systematic random sample of children aged between 9-15 years old was selected for this study. One class was chosen randomly from each school, 10 student was chosen randomly from each grade $(4$ th, 5 th, 6 th grade for primary schools and 1 st, 2 nd, 3 rd grade for preparatory schools) so the total number of student was 240 student.

Tools of the study: The study tool was developed by the investigator. The Structured interviewing questionnaire composed of two tools to collect data for this study.

Children health profile questionnaire was developed by research investigator and includes: 1 st part. Personal data (e.g. age, grade, gender, residence and number of family members etc.). 2 nd part. Child physical health profile assessment data. includes questions concerning children health in these areas: Body Mass Index (BMI) scores and percentile scores based on the children's BMI tool for schools [22]. Physical Health symptomology (e.g. sick days from schools in the last 12 months, general physical health symptoms (headaches, low back pain, eye problems and stomach aches etc.). 3 rd part. Child psychological and social health profile assessment data. It was developed based on Children Manifest Anxiety Scale [23], Children loneliness Scale [24]. Children Aggressive Behavior scale [25], and Attention Deficit Hyper Activity Disorder (ADHD) scale, [26,27]. Items of ADHD was asked to the parents by research investigator through phone or interview. 4 th part. School academic achievement and daily activity assessment data which includes scholastic achievement, attendance to school, child outdoor play and exercise. It was measured by asking children about their daily outdoor play or exercise in terms of hours per day $\subset \subset-$

2- Second tool: Digital technology usage data tool .was developed by the research investigator. Children were asked about digital technology ownership (e.g. cell phone, PCS, iPod/MP3 player etc.) and his/her use of technology in their bedroom. In addition, daily media and technology usage time period (e.g. playing video games, talking on the telephone, texting, listening to music, and playing with technological toys etc.).

Scoring system for tool: Responses was against 3 points likert scale identify the degree of Children Manifest Anxiety part, Children loneliness part, ADHD part and Children Aggressive Behavior part. For yes and no question scoring, a negative response was given zero while a positive response 
was given number one. Validity and reliability of study tools that were designed submitted to a panel of 15 reviewers and experts in the field of community health nursing and psychic nursing and medical health, psychology health, engineering, computer and information technology, press and information collage were asked to revise the tool for its content validity for content validity. Each expert on the panel was asked to examine the instrument for content coverage, clarity, wording, length, format, and overall appearance. Modification of tools was done according to ascertain relevance and completeness.

Ethical and legal considerations: A primary approval to conduct the proposed study was obtained from the Research Ethics Committee, at 29/1/2017 Faculty of Nursing, Cairo University. Participation in this study is entirely voluntary. Each student had the right to accept or refuse participation in the study. Informed consent had been obtained from the student through their parents. Anonymity and confidentiality are assured through coding the data, students were assured that this data was not be reused in another research without permission; data collected was used in the purpose for the research only.

Pilot study: A pilot study was conducted on 24 students who equal $10 \%$ from the study sample from four schools included in the original study settings to assess the feasibility of the study as well as clarity of data collection tool and to determine the needed time for application of the study tool.

\section{Statistical analysis:}

Data were coded, scored, tabulated, and analyzed by compute using "Statistical Package for Social Science" (SPSS windows) Version 22. Numerical data were expressed as mean $\pm \mathrm{SD}$, and range. Quantitative data were expressed as frequency and percentage. For quantitative data comparison and association between study variables was done by using chi-square test. Relations between different numerical variables were tested using Pearson correlation. Probability ( $p$-value) less than 0.05 was considered significant and less than 0.05 was considered as highly significant.

\section{Results}

Part (I): Demographic and scholastic data.

Table (1) revealed that $(52.5 \%)$ of students aged from twelve to fifteen years old, while $(46.3 \%)$ of students ranked as the first child in their families, whereas $(94.2 \%)$ of students live with their parents.
In addition $(73.3 \%)$ of family members were between 5 to 8 persons, $(86.7 \%)$ of mothers had completed their university education and $(66.7 \%)$ of fathers had completed their university education. Additionally the current results shows that $(60.4 \%)$ of the mothers were working, $(47.5 \%)$ of the fathers had governmental work, $(38.3 \%)$ of students like to go to school, $(30.8 \%)$ of them was regularly attend to school and $(11.3 \%)$ of them was participated in school activities, $(22.5 \%)$ of them have participated in sporting activities such as football, swimming, karate and judo respectively. (10.4\%) of students was played in street, (14.6\%) of students spent one hour to less than 2 hours in practicing sporting activities.

Table (1): Percentage distribution of students' personal data regarding their age, gender, and birth order $(\mathrm{N}=240)$.

\begin{tabular}{|c|c|c|}
\hline Items & $\mathrm{N}$ & $\%$ \\
\hline \multicolumn{3}{|l|}{ Age: } \\
\hline 9 years- $<12$ years & 114 & 47.5 \\
\hline 12 years- 15 years & 126 & 52.5 \\
\hline \multirow[t]{2}{*}{ Total } & 240 & 100 \\
\hline & \multicolumn{2}{|c|}{ Mean $=12 \pm 2.1$} \\
\hline \multicolumn{3}{|l|}{ Gender: } \\
\hline Male & 124 & 51.7 \\
\hline Female & 116 & 48.3 \\
\hline \multicolumn{3}{|l|}{ Birth order: } \\
\hline The first & 111 & 46.3 \\
\hline The second & 71 & 29.6 \\
\hline The third or more & 58 & 24.1 \\
\hline
\end{tabular}
dents:

Bio-psycho-social health profile data of stuA- Physical health profile data:

Table (2): Percentage distribution of students' according their weight $(B M I)(n=240)$.

\begin{tabular}{lll}
\hline Items & $\mathrm{N}$ & $\%$ \\
\hline Underweight $(<5$ th\% percentile) & 5 & 2.1 \\
Normal BMI $\quad(5$ th-85th\% percentile) & 75 & 31.3 \\
Overweight or obese $(\geq 85$ th\% percentile) & 81 & 33.7 \\
Obese $(\geq 95$ th $\%$ percentile $)$ & 79 & 32.9 \\
\hline Total & 240 & 100 \\
\hline
\end{tabular}

Table (2) clarifies the distribution of students according their BMI the table reveals that the $33.8 \%$ of them were overweight ( $\geq 85$ th $\%$ percentile). Moreover, $32.6 \%$ of them were obese ( $\geq 95$ th $\%$ percentile). While $31.3 \%$ were normal weight (5 th85 th $\%$ percentile) and $2.1 \%$ of them were underweight $(<5$ th $\%$ percentile $)$. 
Table (3): Percentage distribution of students according their physical self-reported symptoms $(n=240)$.

\begin{tabular}{lll}
\hline Symptoms' affecting body systems & $\mathrm{N}$ & $\%$ \\
\hline Musculoskeletal symptoms': & 201 & 83.75 \\
Shoulders and wrist pain & 147 & 61.25 \\
Neck and back pain & 198 & 82.5 \\
Ophthalmological symptoms': & 135 & 56.25 \\
Tears, redness of the eyes & 49 & 20.4 \\
Pain, burning in the eyes & 51 & 21.25 \\
Itching in the eyes & 38 & 15.8 \\
Problems f eyesight & 31 & 12.9 \\
Neurological symptoms: & 195 & 81.25 \\
Headache & 137 & 57.1 \\
Dizziness & 89 & 37.1 \\
Difficulty falling in sleep & 190 & 79.2 \\
Anxiety & 132 & 55 \\
Digestive symptoms: & 224 & 93.3 \\
Abdominal pain & 11 & 4.6 \\
Forget to eat while using electronic devices & 36 & 15 \\
Over eating while using electronic devices & 204 & 85 \\
\hline
\end{tabular}

All responses are not mutually exclusive:

Regarding students physical self-reported symptoms' (Table 3) reveals that $93.3 \%$ of them have complained of digestive symptoms 'such as over eating while using electronic devices, forget to eat while using electronic devices and have abdominal pain among $85 \%, 15 \% \& 4.6 \%$ respectively. Moreover, $83.75 \%$ of them complained of musculoskeletal symptoms' $82.5 \%$ have neck and back pain and $61.25 \%$ have shoulders and wrist pain. However, $81.25 \%$ of them have complained of neurological symptoms 'such as sleep difficulties, headache, anxiety, and dizziness among $79.2 \%, 57.1 \%$, $55 \%$ \& $37.1 \%$ respectively. Additionally $56.25 \%$ of them have complained of ophthalmological symptoms' such as pain, burning in the eyes, tears, redness of the eyes, itching in the eyes and problems of eyesight among $21.25 \%, 20.4 \%, 15.8 \%$ and $12.9 \%$ respectively.

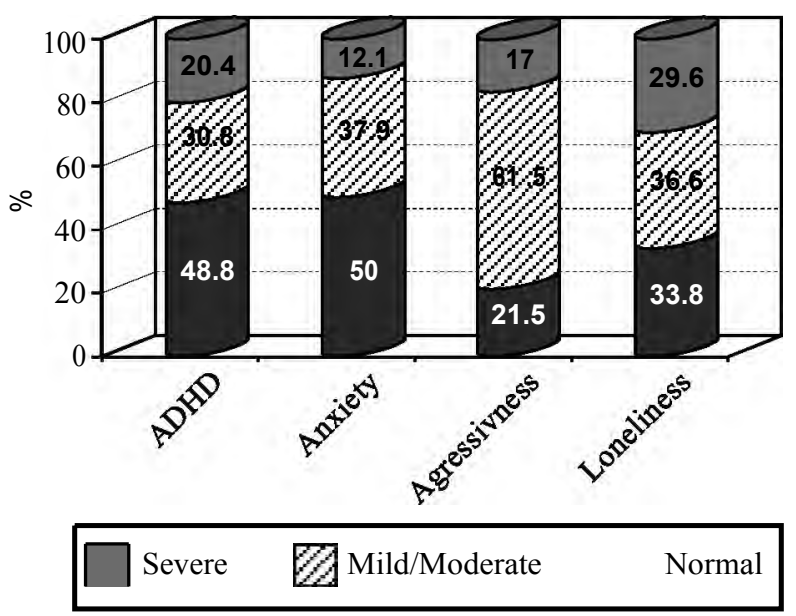

Fig. (1): Psychosocial behavior scales among students.
Regarding self-reported psychosocial behavior total scores among students' Fig. (1) shows that, $29.6 \%$ of students have severe symptoms of loneliness behavior, while $12.1 \%$ of students have severe symptoms of anxiety behavior, moreover $20.4 \%$ of students have severe symptoms of ADHD behavior and $10.5 \%$ of students have severe symptoms of aggressive behavior. Additionally $61.5 \%$ of students have mild/moderate symptoms of aggressive behavior, while $37.9 \%$ of students have mild/moderate symptoms of anxiety behavior, meanwhile $36.6 \%$ of students have mild/moderate symptoms of loneliness behavior and $30.8 \%$ of students have mild/moderate symptoms of ADHD behavior. Meanwhile, $50 \%$ of them are normal, while $33.8 \%$ of them are normal, also $48.8 \%$ of them are normal and $21.5 \%$ of them are normal.

\section{Part (III): Digital technology usage data:}

Table (4): Percentage distribution of types of digital technology present at home $(\mathrm{n}=240)$.

\begin{tabular}{lcc}
\hline Items & $\mathrm{N}$ & $\%$ \\
\hline - Mobile without camera & 27 & 11.3 \\
- Mobile with camera + Wi-Fi & 238 & 99.2 \\
- Laptop & 186 & 77.5 \\
- Tablet & 193 & 80.4 \\
- Radio & 131 & 54.6 \\
- Cassette & 146 & 60.8 \\
- MP3/ipod & 161 & 67.1 \\
- Television & 235 & 97.7 \\
- Video Machine & 154 & 64.2 \\
- DVD player & 174 & 47.9 \\
- Desktop Computer (PC) & 227 & 94.6 \\
- Internet connection at home & 236 & 98.3 \\
- PlayStation or other gaming machines & 115 & 72.5 \\
- Toys handheld in the pocket (ipad) & 174 & 72.5 \\
- Electronic musical instrument such as guitar & 109 & 45.4 \\
or electric piano & & \\
\hline
\end{tabular}

\section{All responses are not mutually exclusive:}

Regarding types of digital technology present at home (Table 4) reveals that $99.2 \%$ of students owned mobile with camera + Wi-Fi. Moreover, $98.3 \%$ of them have internet connection at home, while $97.7 \%$ of them have television at home, additionally $94.6 \%$ of them have desktop computer (PC), however $80.4 \%$ of them have tablet, also $77.5 \%$ of them have laptop, meanwhile $72.5 \%$ of them have play station or other gaming machines and ipad. Additionally (Table 4 ) shows that $67.1 \%$ of them have MP3/ipod, while $64.2 \%$ of them have video machine, also $60.8 \%$ of them have cassette, $54.6 \%$ of them have radio, however $47.9 \%$ of them have DVD player, while $45.4 \%$ of them have electronic musical instrument such as guitar or electric piano and finally $11.3 \%$ of them have mobile without camera. 


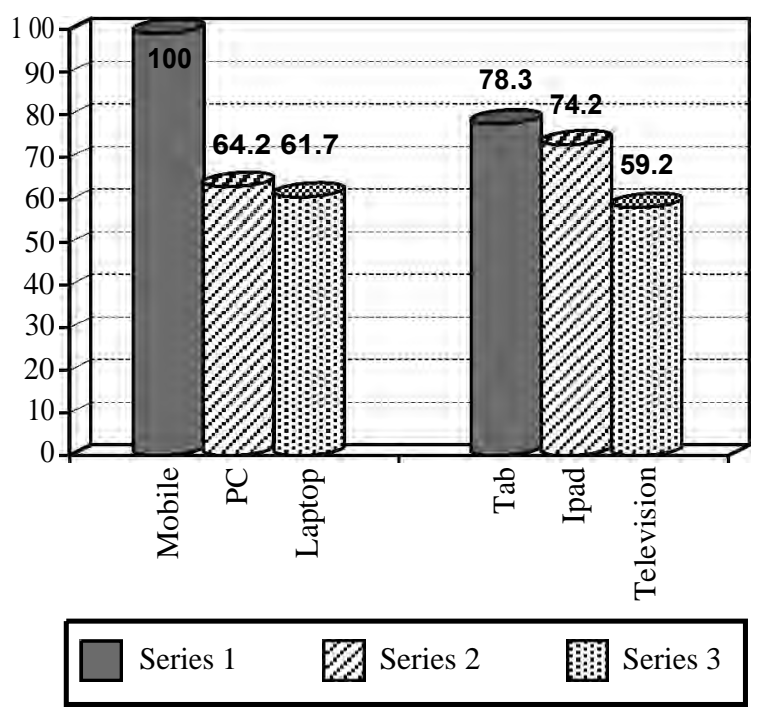

Fig. (2): Digital devices presents at bedroom. All responses are not mutually exclusive.

Regarding percentage distribution of digital devices present in students' bedroom Fig. (2) reveals that $100 \%$ of students keep mobiles in their bedrooms, while $78.3 \%$ of them keep tablets, while $74.2 \%$ of them keep ipad, moreover $64.2 \%$ of them keep PC, also $61.7 \%$ of them keep laptop and $59.2 \%$ keep TV in their bedrooms. Additionally (Table 4) shows that students' most preferable types of digital technology as such $35.4 \%$ of students prefer to use mobile phone continuously, followed by PC, laptop among $24.6 \%$ of the students', followed by Tab, ipad among $15 \%$ of the students, followed by $12.9 \%$ of them watching TV continuously, followed by $12.1 \%$ of them playing Play Station continuously.

Table (5): Percentage distribution of students' according their hours of using digital technology per day $(n=240)$.

\begin{tabular}{lll}
\hline Items & $\mathrm{N}$ & $\%$ \\
\hline - Screen time per day: & & \\
$\quad$ Less than 2 hours. & 6 & 2.5 \\
2 to less than 6 hours. & 85 & 35.4 \\
6 to less than 10 hours & 116 & 48.3 \\
10 hours or more. & 33 & 13.8 \\
- Frequency of time you spend in using of & & \\
$\quad$ digital technology; & & \\
$\quad$ Continuous & 58 & 24.2 \\
$\quad$ Intermittent & 182 & 75.8 \\
\hline
\end{tabular}

Regarding number of hours spent by students' on digital technology usage (Table 5) reveals that $48.3 \%$ of students spent from 6 to less than 10 hours per day, while $35.4 \%$ of them spent from 2 to less than 6 hours per day, furthermore $13.8 \%$ of them spent 10 hours or more per day, moreover $2.5 \%$ of them spent less than 2 hours per day.
Additionally (Table 5) also shows that $75.8 \%$ of students used digital technology intermittently, while $24.2 \%$ of them used digital technology consciously. Results also revealed that most preferable videogames were horror games among $40.8 \%$ of students, while $20.4 \%$ of them prefer action games, moreover $20 \%$ of them prefer entertainment games, while $16.3 \%$ of them prefer Sport-race games also $2.5 \%$ of students prefer intelligence games. Additionally, results also shows that $40 \%$ of students love to play video games with themselves, while $36.3 \%$ of them love to play video games with their siblings, moreover $22.1 \%$ of them love to play video games with their friends also $1.7 \%$ of the them love to play video games with their parents. Meanwhile common places were students' played video games on it were in their bedrooms among $64.2 \%$ of students', while $16.3 \%$ of the them play video games in electronic café (Alcyber), moreover $11.3 \%$ of them play in their friend's house, also $8.3 \%$ of them play video games in their family room.

Table (6): Relationship between the study variables.

\begin{tabular}{|c|c|c|}
\hline \multirow{2}{*}{ Demographic data } & \multicolumn{2}{|c|}{ Screen time } \\
\hline & $r$ & $p$ \\
\hline Age of the students & 0.043 & $p<0.01 * *$ \\
\hline \multirow[t]{2}{*}{ Educational level of the mother } & 0.035 & $-p<0.01 * *$ \\
\hline & Chi & $p$ \\
\hline Mothers work & 112.7 & 0.00001 \\
\hline
\end{tabular}

Table (7): Relation between physical health profile and screen time of digital technology usage among students' $(n=240)$.

\begin{tabular}{lcc}
\hline \multirow{2}{*}{ Physical symptoms } & \multicolumn{2}{c}{ Screen time } \\
\cline { 2 - 3 } & CHI & $p$ \\
\hline Musculoskeletal symptoms & 12.2 & 0.006 \\
Ophthalmological symptoms & 65.2 & 0.00001 \\
Digestive symptoms & 58.7 & 0.0001 \\
Neurological symptoms & 33.8 & 0.00001 \\
BMI & 37.9 & 0.00001 \\
\hline
\end{tabular}

There was a statistical positive significant correlation was found between demographic data of students and screen time. There is negative significant relation was found between mother work and screen time. Moreover, there is positive significant relation was found between physical health problems and screen time. There is appositive significant relation was found between videogames and psychosocial health problems among students. Moreover, there is positive significant relation between movies/serials and anxiety, aggressive symptoms, 
except loneliness symptoms a negative relation was found. Additionally there is positive significant relation was found between screen time and psychosocial health problems among students.

Table (8): Relation between psychosocial health profile and pattern \& screen time of digital technology usage among students' $(\mathrm{n}=240)$.

\begin{tabular}{llcccccccc}
\hline Psychosocial items & \multicolumn{2}{c}{ Aggressive } & \multicolumn{2}{c}{ Loneliness } & \multicolumn{2}{c}{ Anxiety } & \multicolumn{2}{c}{ ADHD } \\
\hline Items & CHI & $p$ & CHI & $p$ & CHI & $p$ & CHI & $p$ \\
\hline Favorites video games & 97.8 & 0.00001 & 80.05 & 0.00001 & 47.03 & 0.0001 & 61.9 & 0.00001 \\
Favorites movies/serials & 110.9 & 0.00001 & 13.1 & 0.10 & 102.8 & 0.00001 & 49.4 & 0.00001 \\
Screen time per day & 78.2 & 0.00001 & 101.4 & 0.00001 & 59.3 & 0.00001 & 108.8 & 0.00001 \\
\hline
\end{tabular}

\section{Discussion}

The results of the current study revealed that more than half of students aged from twelve to fifteen years old and about half of them aged between nine to less than or equal twelve with mean age $(12 \pm 2.1)$. The results of the current study also revealed that more than half of the students were males this goes with a study done by [28], on 2620 Australian students aged between 6-18 years old also found that majority of students aged between 8-14 years and fifty two percent of students were males. Another international study done by [29] between five countries including Egypt, study revealed that more than half of the children aged between 12-15 years old and seventy five percent of students' were males.

The results of the current study also revealed that about half of students ranked as the first child in their families. This result are similar to a study done by [30] on 230 Mansoura students also found that forty percent of students ranked at the first child in the family.

The results of the current study revealed that majority of students live with their parents this goes with [30], who found that sixty nine percent of USA students aged between 9-18 years old lived with their parents. Moreover [31], also found that sixty seven percent of students' lived with their parents.

The results of the current study revealed that about three fourths of students' had 5 to 8 family members, this goes with a study conducted by [31] who found that almost fifty five percent of students had 5-8 family members. This may be due to Egyptian culture that previous change number of family members as a source of family strength, also our culture and tradition about having number of children and family structure (e.g. extended family).

The results of the current study revealed that majority of mothers had completed their university education and two third of fathers had completed their university education. The results was supported by a study done by [30] on 230 Mansoura students who found that seventy seven percent of mothers had completed their university education and seventy four percent of fathers had completed their university education as well.

Regarding mother work the current study revealed that about two third of mothers were working, these results finding completely agree with the results of the a study done by [32], on 8-18 years old children in USA who found that almost sixty percent of mothers were working. Whereas, [7] in California, also found that that only sixty percent of the mother were working.

The current study finding also revealed that about half of the fathers had governmental work. A study done by [7] also found that sixteen percent of the fathers were working full time from research investigator point of view that. From research investigator point of view that in Egypt governmental work means stability. The results of the current study revealed that majority of students have not participated in school activities. The result was supported by a study done by [7] on 316 students of Southern California found that almost sixteen percent of students not participated in school activities. From research investigator point of view that school activities' not interesting and not enough.

Regarding scholastic data of the students the current results revealed that more than one third of students like to go to school and one third of them regularly attend to school. This may be school lessons are not interesting for them and they are not regularly attend because of they are getting late and they are not ready at early to go to school.

The results of the current study illustrate that minority only of children participated in sporting activities outside the school and majority from 
$(22.5 \%)$ of students' played sporting activities in street. Such result was completely agree with results of a study done by [33], on twenty hundred students' of Algeria aged between 7 and 12 years old who found that minority of students have participated in school activities. Additionally, Australian cross sectional study was conducted in order to look at the trend in children's after school activities. Out of 2,940 reports of children's activities, twenty five percent of students involved in physical activity, including organized sports and free play [34].

According to the Centers for Disease Control and Prevention [35], children need one hour or more of physical activity each day. The results of the current study revealed that about two third from $(22.5 \%)$ of students spent only one hour per day playing sporting activities. This result was supported by a study was done by [31] who found that about thirty seven percent of students have participated in sporting activities 2-3 time per week.

In concerning students BMI the results of the current study also revealed that more than one third of students' were overweight or obese. These results were supported by several studies. As regards obesity and overweight among elementary school children, [36], statistical report that thirty four percent of Egyptian aged from (9-15) years old students were overweight and obese. Meanwhile [7], on 316 students of Southern California area aged between 9-18 years old to a study" Media and technology use predicts ill-being among children, preteens and teenagers independent of the negative health impacts of exercise and eating habits" found that fifty two percent of students' were either overweight or at risk of being obese. Moreover, [37], who found that thirty percent of Hispanic children at risk of obesity [38]. Found that in USA almost thirty two percent of children are overweight or obese [39]. Reported that fifty percent of Canadian children aged between 7 to 13 years old were overweight and one third of them were obese. In the same respect Recent Egyptian study done by [40], on school children aged between 8-12yrs old found that, prevalence of childhood overweight and obesity was almost twenty four percent and almost twenty percent respectively.

Regarding students sick absent days the result of the current study shows that more than two fifth of students were absent from 11 to 15 day. This may be due to students un healthy nutritional diet, decreasing of physical activity, increasing screen time, high sedentary life style which lead to poor health condition.

Regarding physical symptoms current study revealed that almost all of them have complain of digestive symptoms' regarding physical health profile self-reported symptoms that majority of students were over eating while using electronic devices. This results supported by a study done by [31] on 298 students metropolitan Perth, Western Australia aged between 11-12 years old to a study "Individual, Social, and Physical Environment Factors Associated With Electronic Media Use Among Children: Sedentary Behavior at Home" found that almost seventy eight percent of students over eating while using electronic devices. This may be because of eating a lot of fast food and snacks during using digital devices not healthy food and scabbing family meals.

The results of the current study revealed that majority of students physical health profile selfreported symptoms complained of musculoskeletal symptoms. Among the main finding of musculoskeletal symptoms' was that majority of students have neck and back pain and bout two third of students have shoulder and wrist pain. This result supported by study done by [41], on 643 Australian students to a study" screen-based media use clusters are related to other activity behaviors and health indicators in school age children "that found that ninety three percent of students had back pain and forty five percent of them had neck pain. From research investigator point of view that inappropriate $8+9$ positions while using digital technology and no body mechanics and hours of using digital technology lead to musculoskeletal symptoms.

The results of the current study revealed that majority of them have complained of neurological symptoms regarding physical health profile selfreported symptoms eighty percent of students' have sleep difficulties (night maries, insomnia difficult falling in sleep). This result was supported by a study done by [42], on school age children the results was that about forty one had sleep difficulties and about forty two had insomnia. Another study supported the result of the study done by [43] on 1,287 Australian students'. Aged between 1218 years to study "Sleep Interference Effects of Pathological Electronic Media Use during Adolescence "that found that seventy one of students have non-optimal sleep duration on weekday and fifty three of them have non-optimal sleep duration on weekend nights, also $75 \%$ of U.S. children aged 9 and 10 years are sleep deprived to the extent that it significantly impacts on their grades [44]. Addi- 
tionally such a study supported the results of the current study done by [45] on 5-17 years old multiple European countries Brazil, Canada, China, New Zealand, Saudi Arabia, and Taiwan. Time and Sleep among School-Aged Children's found that ninety percent of students' had sleep problems' and difficult falling in sleep.

Additionally two third of them have complained of ophthalmological symptoms' regarding physical health profile self-reported symptoms one fifth of them had complained of pain, burning in the eyes, and one fifth of them also complained of tears, redness of the eyes. Such a study supported the result of the current study done by [45] found that twenty one percent of Algerian students aged from had eye problems.

The results of the current study revealed that two third of students have mild/moderate symptoms of aggressive behavior, moreover about minority of students have severe symptoms of aggressive behavior, such a study supported the current result done [46] on 720 Egyptian students in Beni-Suef City, aged from 11-15 years old who found that mild/moderate total aggression among students were about seventy eight percent. Additionally Egyptian study supported the current result done by [47] on children aged between 11-17 years old about Physical fighting among Egyptian adolescents: Social and demographic correlates found that, $31 \%$ of participants reported being involved in two or more physical fights and more than half of all participants reported being bullied.

The results of the current a study shows that more than one third of students have mild/moderate symptoms of loneliness behavior, moreover almost one third of students have severe symptoms of loneliness behavior, a study results similar to the current results was conducted by [48] on 260 USA students aged between 10-15 years old to a study "The Impact of Shyness on Loneliness, Social Anxiety, and School Liking in Late Childhood" fond that thirty two percent of students have mild/ moderate symptoms of loneliness behavior moreover almost thirty one percent of students have severe symptoms of loneliness behavior.

The results of the current a study shows that more than one third of students have mild/moderate symptoms of anxiety behavior, moreover minority of students have severe symptoms of anxiety behavior, a study results supported the current results was conducted by [48] on 260 US students aged between 10-15 years old to a study "The Impact of Shyness on Loneliness, Social Anxiety, and
School Liking in Late Childhood" fond that fifty two percent of students have mild/moderate symptoms of anxiety behavior moreover almost twelve percent of students have severe symptoms of anxiety behavior. Additionally a study contradicted the current results done by [46] on 720 students in governmental schools in benisuef city, Egypt aged from 11-15 years old found that severe and moderate total anxiety among students were $89.6 \%$ and $80.1 \%$ respectively.

The results of the current a study shows that more than one third of students have mild/moderate symptoms of ADHD behavior, moreover one fifth of students have severe symptoms of ADHD behavior. Such a study supported the current result done by [49], the results of the study estimated that the prevalence of ADHD in Fayoum City (Egypt) among 420 school-age children aged between 6 to 14 years the prevalence of ADHD in Fayoum City was $20.5 \%$, with $33.8 \%$ among boys and $6.8 \%$ among girls. Another study conducted in Assuit city Egypt to estimate the prevalence of ADHD among elementary schools children in Assiut City of both sex with age ranged from 8-10.5 years. The study revealed that the prevalence rate of ADHD was $6 \%$ among elementary schools [50].

In relation to types of digital technology present at students homes the results of the current study found that almost all of students owned mobile with camera $+\mathrm{Wi}-\mathrm{Fi}$, moreover, majority of them have Internet connection, television, desktop computer (PC) at home respectively. However more than two third of them have tablet, play station or other gaming machines, ipad and MP3/ipod. While more half of them have video machine, cassette and radio respectively, however about half of them have DVD player and electronic musical instrument such as guitar or electric piano respectively and finally minority $(11.3 \%)$ of them have mobile without camera in their home [51]. Conducted a study supported the results of the current a study on 1,287 Australian students aged between 12-18 years. Who found that $(91 \%)$ of students owned mobile phone or smartphone, $(89 \%)$ had portable music player, $(86 \%)$ had laptop, $(78 \%)$ videogaming console, $(71 \%)$ personal computer, and $(37 \%)$ had tablet devices. The results supported by such a study conducted by Office of Communications [52], on UK students aged between 5-15 years old to a study "children and parents: Media use and attitudes report" about UK children aged between 5-15 years old about devices present at home old two third of them had net connection, $(80 \%)$ had tablet, $(52 \%)$ had mobile, $(67 \%)$ had 
laptop and PC, (66\%) had game consoles, $(56 \%)$ had DVD and $(33 \%)$ had radio in their home.

In relation to types of digital technology students keep in their bedrooms the results of the current study revealed that all of students keep mobiles in their bedrooms, while three fourths of them keep tablets, of them keep ipad, moreover, about two third of them keep PC, of them keep laptop and more than half keep TV in their bedrooms, the results also revealed that majority of students have more than three digital devices in their bed rooms. National Sleep Foundation's Sleep in America Poll supported the current results, stated that almost all children had at least 1-4 media electronic device in their bedroom, among the devices reported were televisions (57\%), music players (90\%), video game consoles (43\%), computers $(28 \%)$, and phones (64\%). Also a survey resulted in Egypt done by [29] found that $91 \%$ of Egyptian children own a mobile phone. This is as high as $60 \%$ for nine year olds, furthermore $16 \%$ of child mobile users have Smartphone's, $94 \%$ when looking at child's smart phone users $28.9 \%$. The largest percentage of children using tablets is in Egypt $18.4 \%$. Additionally a study supported the current result done by a pediatric office in a Philadelphia showed that of the 100 children ranging in age from 12 to 18 years, two-thirds had a television in their bedroom, almost one-third had a computer, almost $80 \%$ had a digital music player, and $90 \%$ had a cellular phone in their bedroom [53,54], also comparative study conducted by [29] in four Arab countries, including Algeria, Egypt, Iraq and Saudi Arabia about Children's use of mobile phones. The main results were $81 \%$ of children aged 8 to 18 currently use a mobile phone, and one in three owning a smartphone. However tablet usage amongst children surveyed at $28 \%$ [20]. In the same line another study supported the results done by GSMA NTT Do Como on five different countries including Egypt shows that Personal Computers (PCs) are the most commonly used devices to access the internet $(61.1 \%)$, followed by game consoles (29\%). The survey has also showed that tablet use is relatively low. It was $18 \%$ penetration in Egypt and Chile, while $7 \%$ in Indonesia and between 5-7\% in Japan and India. It was also found that $54 \%$ of children use their mobile to access internet, percentage increased to over $87 \%$ of Smartphone users [55]. Such a studies supported the current result done by $[\mathbf{7 , 9 , 3 1 , 3 2 ]}$, reported that between $(75 \%$ to $85 \%$ ) of students have more than three devices in their bedroom.

Concerning students most preferable types of digital technology, the results of the current study revealed that more than one third students prefer to use mobile phone continuously, followed by PC, laptop among about one fourth of students', followed by Tab, ipad among minority of students, followed by of them watching TV and playing PlayStation continuously. Most of the research supports the results of the current study that the majority of the students prefer using mobile phones/ tablets, watching TV and using pc and game consoles $[\mathbf{5 , 7 , 9 , 2 9 , 5 2 , 5 6 ]}$.

Another a study supported the current results conducted by [52] on 8-18 years old students found that eighty percent of students prefer watching TV followed by seventy nine percent prefer using their mobile continuously, followed by forty nine percent of them prefer using tablet continuously. Additionally [7], found that seventy seven percent of American students' prefer using game consoles, followed by sixty seven percent prefer watching TV, while sixty six percent of them prefer using ipod, $\mathrm{mp} 3$, moreover forty percent prefer their mobile phone, also twenty five prefer using PC and sixteen percent prefer using laptop. Moreover, study supported the results of the current results done by [56] on North Carolina, students USA to measure the effect of technology on face-to-face communication. Drago, mentioned that All (100) student owned a smartphone or tablet. Almost all students (97\%) bring their cell phones or tablets with them every day.

Concerning the pattern of digital technology usage among students the results of the current study revealed that more than one third of students watching competition programs, and almost one third of students watching horror movies and serials, while more than one fourth of them watching action movies. In relation to digital technology activities by TV the result of the current a study revealed that more than one fifth of students watch movies and serials on TV such a study support the current result done by [30], on 230 Mansoura, Egypt students to a study " The Relationship between use of Technology and Parent-Adolescents Social relationship" found that fifty four percent of students watching TV mostly and prefer movies and serials.

In relation to most preferable types of video games to students the current results revealed that two fifth of students prefer horror games, followed by one fifth of students prefer action games, moreover two fifth of students love to play video games with themselves and two third of students' played video games in their bedrooms, such a study agreed with current results done by [33] on 200 Algerian students aged between 7-12 years old to a study" effect of video games on students behavior" found 
that almost fifty five percent of students prefer horror and action games, also found that forty six percent of them love to play alone and ninety two percent of students' played video games in their bedrooms. That may be related to majority of video games built in competition and aggressiveness basis.

Additionally a study are similar to the result of the current study done by [57] revealed that most common types of games preferred by American children were horror and action games, also [58], report that violent video gaming were among the top 20 best-selling video games in 2013. Additionally another study supported the results of the current study was conducted by [59], on 67 Kansas City, Missouri students' to a study "effect of violent video games on emotion modulation of startle" found that most preferable video games for both gender were violent video games.

Concerning digital technology activities while playing video games the result of the current a study revealed that almost one third of students Play games on their (PC) or smartphone by themselves, such a study supported the current result done by [33], on Algerian children aged between found that fifty six percent play video games on their PC (PC) or smartphone by themselves, also ninety six percent of children today say they would rather use their computers and other hand-held devices for gaming purposes than for homework or internet research [60].

Regarding screen time, students spent using digital technology the results of the current study revealed that more than two third of students exceeded the recommended hours by AAP, about half of them spent from 6 to less than 10 hours per day. While more than one third of them spent from 2 to less than 6 hours per day, furthermore minority of them spent 10 hours or more per day. Additionally almost three percent of students spend the recommended hours using digital technology. Dramatically two third of students used digital technology intermittently. The current results were supported by variety of studies conducted by the [54] report that children spend an average of sevenhour a day using various electronic devices, while [9] found that Children use 7.5 and teens 9 hours per day of digital technologies, in the same line study conducted in UK stated that children aged 4-15 years watched an average of 13 hours using digital technology [52], moreover, [61] found that almost half of US aged between 6-17 year-olds exceeded the recommended hours by AAP. Additionally a study done by [16] on 299 students in
KSA aged from 4-16 years old found that almost fifty one percent of students spend more than 3 hours using digital technology, meanwhile, [28] indicated that $63 \%$ of Australian children exceeded the recommendation of $<2$ hours per day using digital technology by AAP. Moreover, [61] found that $48.7 \%$ of USA children had exceeded the recommended screen time. Meanwhile, research done by [62] on New York children revealed that all this screen time equates to media consumption of nearly 35 hours a week. Majority of previous studies agreed with the current results, also in UK [62], found excessive prevalence rates of screen time among children.

The results of the current study revealed that all of students use the internet to play games online \& $\log$ in Facebook and other sites, moreover majority of them use the internet to watch movie and movies ads, while of them use the internet to listen to music. Such a study supported the current results done by [52] on UK Children aged between 4-15 years to a study "Children and parents: Media use and attitudes report" found that two third of them had net connection and eighty seven percent use net for you tube, apps, also fifty eight percent use net for playing games, and fifty five percent of them use net to watch movies and movies advertise. Regarding digital technology activities by using the internet the result of the current a study reveals that more than one fifth $(22.1 \%)$ of students' browse Facebook, while (21.3\%) of them search the internet for video clips on you tube from any device such a study agreed with the result of the current a study done by [62] on new york children revealed ninety six percent of children surf the internet, download music, Netflix, and YouTube. They use social media sites such as Snap Chat, Instgram, Facebook and Twitter.

Concerning digital technology activities by using mobile phone, the results of the current a study shows that more than one third of students use their mobile for send and receive phone calls and checking for text messages, also about one fourth of students use their mobile for listening to music and capture pictures. Such a study agreed with current result done by [11] on 8-18 years USA children to a study "Determining the Effects of Technology on Children" found that $72 \%$ of them made phone calls, $62 \%$ of them texting on their mobile phone. May be related to students owning phone in earlier ages and no rules set about availability of using it. In the same line a study supported the result of the current study done by [29] on 8 18 years old children in five countries including Egypt found that call frequency is high, with $54 \%$ 
of children making six or more calls a day also $54 \%$ of all children who use mobile to access the internet this increases entertainment app use is most popular at $66 \%$ among children who use or download apps. The current results supported by Such a study done by [20] in five Arabic countries found that $27 \%$ of children who use mobile phones use the mobile internet for school in Saudi Arabia, followed by $15 \%$ of Algerian and 13\% of Egyptian children. However ringtones, video games, music and videos are the most popular type of internet content accessed by children, followed by internet games, moreover [63] found that texting is the ultimate social tool for children with $65 \%$ texting on a daily basis.

Regarding digital technology activities by using personal computer, the results of the current study revealed that less than one fifth of the students Watch and download, games, videos, songs on their personal computer. According to international comparison survey between five different countries including Egypt to assess children use of digital technology, the result of this study shows that almost sixty two percent of students told that their personal computers are the most commonly used device to access the internet [55]

Regarding relation between screen time and demographic data of students, results of the current study revealed that there was a highly statistical significant positive correlation between age, and screen time where hours of media usage increasing gradually with age of students this may be because children gradually get attached to a variety of digital technology devices so that lead to consume more time during using of digital technology. This results was supported by such a studies done by [64] on elementary school children in new york city who found that younger generation is growing up surrounded with all forms of technology, primary aged students engaging with I-pads, cell phones, video games, computer games and so much more and screen time increase gradually with the age. Moreover, [52] in UK stated that Children aged 415 years watched an average of 13 hours using Digital technology and increase with age. Moreover, $[\mathbf{9 , 3 1}, 32]$ found that there was significant relation between getting older and consuming more screen time than recommended by AAP.

The current results revealed a highly statistical negative significant relation between educational level of the mother and screen time, in where screen time increased when educational level of the mothers education decreased also, screen time increase with low educated mother because of ignorance of the mother about negative effect of the digital technology that lead to uncontrolled screen time for their children. This results was supported by such a studies done by [64] on elementary school children in New York city to a study "Effects of Technology on Literacy Skills and Motivation to Read and Write" found that literacy skills begin at home, students are exposed different types of digital technology and so much more at an early age. The level of engagement of screen time affected by education of the mother. Moreover another a study agreed with current results done by [65] on 10-15 years old in Finland to a study "Young Children as Internet Users and Parents Perspectives" found that majority of parents concern about excessive screen time during using digital technology for their children. However results of a study done by [66] on 453 children in five European countries reported that there is a significant association between screen time and educational level of the parents.

The results also show a highly statistical positive significant relation between working condition of the mother and screen time. The current results was supported by such a study done by [6] on 316 students of Southern California found significant relation between screen time and working condition of the mother. This may be because absence of the mother from the home due to work and busy mothers don't have time to control screen time for their children.

The current results revealed that a highly statistical positive significant relation between physical health problems and screen time for children including (digestive symptoms, musculoskeletal symptoms, neurological symptoms and ophthalmological symptoms), this may be related to many factors that leads to physical health symptoms such as wrong position during using digital device, less distance between digital device and eyes of the child, un healthy eating during using digital technology such as (junk food, cola, ect.). The current results was supported by such a studies done by $[9,67,68]$. In America and Europe [69]. [21] in KSA \& [6] in Southern California \& [43] in Australia \& [45] in multiple European countries Brazil, Canada, China, New Zealand, Saudi Arabia, and Taiwan, [70] in Australia \& [71]. Reported that there is a significant association between screen time and physical health problems among students.

The results also shows highly statistical significant positive relation between students weight and screen time, its cross sectional relation whereas 
weight of the students increase gradually for the student who spend more than 2 hours using digital technology. Such as (un healthy food, lack of physical activities and exceeded appropriate screen time) that lead to increase BMI also Television advertising attract children to fast food. This results were supported by such a study done by [15] in Tanzania [36,40] in Egypt \& [66] in five European countries, [7] in USA \& [72] in Egypt reported that there is a significant association between screen time and overweight/obesity among students.

Regarding relation between movies and serials/ video games/screen time and psycho social health problems among students. The current results revealed that highly statistical significant positive relation was found between favorite's movies and serials/video games/screen time and psychosocial health problems among elementary school students. The results of the current study revealed that horror and action movies and serials and video games increased level of psychosocial health problems such as (aggressiveness level, anxiety level, loneliness level, ADHD level) among students. This may be because all action and horror movies and serials/video games contain violent content that lead to more aggressive thoughts and students implicate this content in their real life. Moreover, horror and action movies \& serials/video games build on increasing level of anxiety to give pleasure of continuity. In addition this may be related to that horror and action movies \& serials/video games had violent and action content that may lead to ADHD because it's enhance hyperactivity and affect children's attention. Meanwhile this may be because of horror and action video games in which that lead to increase level of loneliness because of students played video games alone in their bedroom and listen to movies and serials for long time that lead to decrease family time and increasing sensation of loneliness, students also become isolated with no social life. The results also revealed that there was no statistical significant correlation between horror and action movies, serials and loneliness level among students' this may be because the content of the movies and serials not affect loneliness sensation but only the time spent in front of them.

The results of the current study also shows that there was highly statistical positive significant relations between screen time and psychosocial problems such as (aggressiveness level, anxiety level, loneliness level, ADHD level) among students, where majority of the students who exceeded the recommended screen time during using digital technology that lead to increase level of aggressiveness, anxiety level, loneliness level and ADHD level. This may be related to AAP recommendation that all children from 9-15 years should not exposure to screen time more than 2 hours per day exceeding the recommended time by AAP lead to psychosocial health problems among students. In the same line a studies supported the current results of the study about movies and serials/video games/ screen time and psycho social health problems among students. Done by [30,46] in Egypt. [49] in Egypt \& [73] in USA, \& [10] in Massachusetts \& $[74,75]$ in USA. Found that there is a significant positive association between movies \& serials/ video games/screen time and psycho social health problems among students.

\section{In conclusion:}

There was bio psycho social health problems among elementary school children aged between 9-15 years old using digital technology in BeniSuef City included (digestive, musculoskeletal, neurological, ophthalmological) health problems, also there was psychosocial health problems among students such as (aggressive, anxiety, loneliness, ADHD) health symptoms. It is also important to notice that majority of students were overweight or obese. It is highlighted by the present study that there was a significant association between student' exposure to types of digital technology/screen time and bio-psycho-social health problems. Dramatically majority of students exceeded the recommended screen time by AAP and majority of them use more than 3 types of digital technology in their bedroom.

\section{Recommendations:}

Based on the current finding of the study, the following recommendation was suggested:

- Activate the role of Community Health Nurse (CHN) in schools and health services areas through applying frequent educational sessions about a balanced digital technology management and how to control negative effect, health hazards and screen time of digital technology for students.

- Future research can be recommended for further studies such as: (1) Assess bio psycho social health profile for children in governmental school in different ages. (2) Effect of digital technology on (school achievement, on children development, on play, Communication skills, relation with their parents, prosaically behavior). (3) Causative factors leading to increase digital technology screen time. 


\section{References}

1- NIES M. and MCEWEN M.: Community Health Nursing: Promoting the health of populations. 4 th ed.Canda: Saunders. Elsevier Journal, 285-9, 2011.

2- GHOSH G.: Community health nursing. (1 st ed). Kumar, S. New Delhi, 2016.

3- SINGER K.: An Electronic Silent Spring Newsletter. Retrieved August 10, 2016, from http://www. electronicsilentspring.com/july-2016-newsletter/, 2016.

4- FAZEL M.S., HOAGWOOD K., STEPHAN S. and FORD T.: Mental health interventions in schools (5): 377-87. Lancet Psychiatry Journal. From http://www.thelancet. com/pdfs/journals/lanpsy/PII S2215-03 66(14) 70312-8.pdf, 2015.

5- HATCH and KRISTINA E.: "Determining the Effects of Technology on Children": Senior Honors Projects. Paper 260.retrieved 7,june,2016.from http://digitalcommons.uri. edu/srhonorsprog/260PDF, 2011.

6- DUNCKLEY V. and GRAY MATTERS.: Too Much Screen Time Damages the Brain-Neuroimaging research shows excessive screen time damages the brain. Psychology Today, Mental Wealth. Retrieved June 5, 2016, from http://www.psychologytoday.com/blog/mentalwealth/201402/gray-matters-too-much-screen-timedamages-the-brain. 2014.

7- ROSEN L.D., LIM A.F., FELT J., CARRIER L.M., CHEEVER N.A., LARA-RUIZ J.M. and ROKKUM J.: Media and technology use predicts ill-being among children, preteens and teenagers independent of the negative health impacts of exercise and eating habits. Computers in Human Behavior, 35: 364-75. Sience Direct Journal. http://doi.org/10.1016/i.chb.2014.01.036, 2014.

8- RIDEOUT V.J., FOEHR U.G. and ROBERTS D.F.: Generation M2: Media in the Lives of 8-to 18-Year-Olds. Menlo Park CA: Kaiser Family Foundation; 2010.11. Kaiser Family Foundation. Media multitasking among American youth: Prevalence, predictors and pairings-key findings. http://www.kff.org/entmedia/7593.cfm.

9- ROWAN C.: A research review regarding the impact of technology on child development, behavior, and academic performance. Zone'in Programs, Inc. Retrieved august 10, 2016, from http://www.zoneinworkshops.com/zoneinfact-sheet.htmlpdf, 2016.

10- SAMPASA-KANYINGA H. and LEWIS R.F.: Frequent Use of Social Networking Sites Is Associated with Poor Psychological Functioning Among Children and Adolescents. Journal of Cyberpsychology, Behavior, and Social Networking. July, 18 (7): 380-5, 2015.

11- HATCH and KRISTINA E.: Determining the effects of technology on children, senior projects. Journal of Educational Sciences: Theory \& Practice (ESTP), 16 (5): 171 1735. From http://www.dailymail.co.uk/sciencetech/ artic le-2175 674/How-gadgets-internet-turning-nati onemotional-basket-cases.html\#ixzz2PSK3NAev, 2016.

12- American Medical Association: Child hood obesity facts. American Medical Association Journal, Retrieved June 2017. from https://www.fairfieldpaschools.org/cms/lib/ PA01000417/Centricity/Domain/3 5/Childhood\%20Obe sity\%20Facts.pdf, 2016.
13- CAMERON A.J., VAN STRALEN M.M., BRAGG J., SALMON J., BEER E., CHINAPAW M.J.M., et al.: Television in the bedroom and increased body weight: Potential explanations for their relationship among European schoolchildren. Pediatric Obesity, 8: 130-41. Retrieved April 12, 2016, from http://dx.doi.org/10.1016/ j.chb.2014.01.036, 2012.

14- National Heart Lung and Blood Institute: Aim for a Healthy Weight. August 24. Available from: http:// . www.nhlbi.nih.gov/health/educational/lose wt/. 2016.

15-PANGANI, ISMAњ N. FESTUS K. KIPLAMAI, 2 JANE W. KAMAU, 2 and VINCENT O. ANYWHERE: Prevalence of Overweight and Obesity among Primary School Children Aged 8-13 Years in Dar Es Salaam City, Tanzania. Journal of Advances in Preventive Medicine, 1-6. Retrieved September 3, 2016, from http://dx.doi.org/10.1155/ 2016/1345017, 2016

16- ABO AL-RUB M. and ALQUSERI E.: (Behavioral problems associated with using smart phones among children from the parents' point of view in light of some variables. Retrieve,djune, 2017 from http://content.mandumah.com/ download?t=17c 15219e04ad2875b 1 e8f00e48aff91bb3 8e20b\&f=JjpmE/AOpWyW27SUSUqZbKEEp0T yofW9GCih1Gx0lgM=, 2014.

17- WAHDAN N., EL-NIMR R., KOTB and A. WAHDAN 3: Risk of aggression and criminal behaviour among adolescents living in Alexandria Governorate, Egypt Eastern Mediterranean Health Journal265-271. http:// . applications. emro.who. int/emhj/v20/04/EMHJ 201420 4_265_272.pdf?ua=1, 2014.

18- American Academy of Pediatrics: Retrieved July, 25, 2016.

19- JACKSON N.: GSM Association \& NTT DOCOMO, Inc international comparison retrieved July 8, 2016, from http://www.gsma.com/publicpolicy/wpcontent/uploads/ 2012/06/DO COMO_Rep ort2810_EXEC S UM_Ar.pdf, 2011.

20- LYNCH S.: Children use of mobile phone, GSM Association \& NTT DOCOMO international study. Retrieved, August 3, 2016, from http://www.gsma.com/ publicpolicy/wp-content/uploads/2014/02/GSMA-NTT-DOCOMOChildrenReport_ExecSummary_RR_Web1.pdf, 2013.

21- AL-HADLAQ A.: The advantages and disadvantages of playing electronic games and motives of the playing from the viewpoints of public education students in Riyad City. Retrieved September 1, 2016, from http://www.assakina. . com/studies/57791.html\#ixzz4INp9yM2Updf, 2014.

22- CDC: Body mass index. Retrieved from <http://www.cdc. gov/healthyweight/ assessing/bmi>, 2007.

23- ABD EL-HAMID M.: Children manifest anxiety scale. Dar Elnahda El-Massyria, Cairo, 1991.

24- EL-BEHERY A.: Childern lonliness Scale. Dar Elnahda Elmassyria, 1998, Cairo.

25- MELEGY A.: Childern Aggressive Behavior Scale. ElAnglo Library, 1997, Cairo.

26- EL-SAMANODY E.S.: ADHD scale. Dar El-Nahda Elmasria, Cairo, 1991.

27- American Psychological Association: Retrieved May, 10, 2016. An Update on Causes and Consequences PEDIATRICS Accessed November 14, 2013 134, 921, 931 https:// 
www.winsor.edu/uploaded/parents/winsor this week/A 11_School/Sleep_Paper.pdf, 2010.

28- HOUGHTON, et al.: Virtually impossible: Limiting Australian children and adolescents daily screen based media use. Journal BMC Public Health. Retrieved June,7, 2017. From https://doi.org/10.1186/1471-2458-15-5, 2015.

29- GSMA, INC, Association: Children's use of mobile phones: An international comparison. NTT DOCOMO. Inc., Japan: Mobile Society Research Institute Journal of Education and Practice, v.7 n.14 p.168-78, 2013.

30- MOAWAD, GEHAN EL-NABAWY AHMED; EBRAHEM and GAWHARA GAD SOLIMAN: The Relationship between Use of Technology and Parent-Adolescents Social Relationship. Journal of Education and Practice, v.7 n. 14 p.168-78, 2016. From https://files.eric.ed.gov/ fulltext/EJ1103022.pdf, 2016.

31- GRANICH J., ROSENBERG M., KNUIMAN M. and TIMPERIO A.: Individual, Social, and Physical Environment Factors Associated With Electronic Media Use Among Children: Sedentary Behavior at Home. Journal of Physical Activity \& Health, 8: 613-25, 2011.

32- RIDEOUT V.J., FOEHR U.G. and ROBERTS D.F.: Generation M2: Media in the Lives of 8-to 18-Year-Olds. Menlo Park CA: Kaiser Family Foundation; 2010. 11. Kaiser Family Foundation. Media multitasking among American youth: prevalence, predictors and pairings-key findings. http://www.kff.org/entmedia/7593.cfm.

33- QUIDER M.: The effect of video games on Algerians children behavior. Retrieved March, 2017. From, http:// 193.194.83.98/ispui/bitstream/1635/11557/1/KOUIDE R_MERIEM.PDF.pdf, 2012.

34- ENGELEN, et al.: The Simultaneous Influence of National Culture and Market Turbulence on Entrepreneurial Orientation: A Nine-country Study. Journal of International Management. 21: 18-30 https://pdfs.semanticscholar.org/ 350c/a0a1e7f40866a49a85ef36de7e5172ec5309.pdf, 2015.

35- CDC: How much physical activity do children need? <http://www.cdc.gov/physicalactivity/everyone/ guidelines/children.html>. Committee on Public Education (2001). Children, adolescents, and television. Pediatrics, 107: 423-6, 2013c.

36- Unicef: Children in Egypt STATISTICAL DIGEST. From https://www.unicef.org/egypt/eg Ch 12 Youth and Adolescence_2015.pdf, 2015.

37- FENG, et al.: Effects of TV in the bedroom on young Hispanic children. Pub Med Journal. (5): 310-8. Jun., 25, 2017. Doi: 10.4278/ajhp.080930-QUAN-228, 2011.

38- OGDEN C.L., CARROLL M.D., KIT B.K. and FLEGAL K.M.: Prevalence of childhood and adult obesity in the United States, 2011-2012. Journal of the American Medical Association, 311 (8): 806-14. Doi: 10.1001/jama.2014.732, 2014

39- STATISTICS CANADA: Fitness of Canadian Children and Youth: Results from the 2007-2009 Canadian Health Measures Survey. Retrieved on April 30, 2010 from http:// www.statcan.gc.ca/pub/82-003-x/2010001/article/ 11065/key-cle-eng.htm, 2010.

40- TAHA A.A. and MARAWAN H.M.: Socio-behavioral Determinants of overweight and obesity in Egyptian
Primary School Children. Journal of Child and Adolescent Behavior. 3 : 23 6. Doi:10.4172/2375-4494. 100023 6, 2015.

41- STRAKER L., SMITH A., HANDS B., OLDS T. and ABBOTT R.: Screen-based media use clusters are related to other activity behaviors and health indicators in adolescents. Journal BMC Public Health, 13: 1174. From Doi: 10.1186/1471-2458-13-1174, 2013.

42- SCHLARB A.A., KULESSA D. and GULEWITSCH M.D.: Sleep characteristics, sleep problems, and associations of self-efficacy among German university students. Nat. Sci. Sleep, 4: 1-7, retrieved Feb. 9, 2017. From Doi: 10.2147/NSS.S27971, 2012.

43- KING D.L. and DELFABBRO P.H.: The cognitive psychology of Internet gaming disorder. Clinical psychology review, 34 (4): 298-3 08. Doi: 10.1016/j .cpr.2014. 03.006 , 2014.

44- Boston College: https://www.bc.edu/publications/factbook/ 10-19/12_13.html, 2012.

45- HALE L. and GUAN S.: Screen Time and Sleep among School-Aged Children and Adolescents: A Systematic Literature Review. Sleep Medicine Reviews, 21: 50-8. http://doi.org/10.1016/j.smrv.2014.07.007, 2015.

46- FATHY O.: Pupils Maltreatment in the Governmental Preparatory Schools in Beni-Suef City. Master Thesis, 2016.

47- CELEDONIA, et al.: Physical fighting among Egyptian adolescents: Social and demographic correlates among a nationally representative sample. Peer Journal, 1: e125; 1-13 Doi 10.7717/peerj.125-https://peerj.com/articles/ 125.pdf, 2013.

48- WALKER and CHARITY M.: "The Impact of Shyness on Loneliness, Social Anxiety, and School Liking in Late Childhood". Electronic Theses and Dissertations. 948. From https://digitalcommons.du.edu/etd/948, 2011.

49- ABOUL-ATA and AMIN: The Prevalence of ADHD in Fayoum City (Egypt) Among School-Age Children, Journal of Attention Disorders, Doi: https://doi.org/10.1177/ $1087054715576917,2015$.

50- HAMDY N. EL-TALLAWY, WAGEEH A. HASSAN, ABD EL-RAKEEP A. EL-BEHARY and GHAYDAA A. SHEHATA: Prevalence of Attention Deficit Hyperactivity Disorder Among Elementary Schools Children in Assiut City-Egypt. Egypt J. Neurol. Psychiat. Neurosurg., 42 (2): 517-26. http://www.ejnpn.org/Articles/298/ 2005422024. pdf, 2005.

51- DANIEL L. KING, PAUL H. DELFABBRO, TARA ZWAANS and DEAN KAPTSIS: Sleep Interference Effects of Pathological Electronic MediaUse during Adolescence 12: 21-35 Int. Journal Ment. Health Addiction https://link.springer.com/content/pdf/10.1007\%2Fs11469013-9461-2.pdf, 2013.

52- Office of Communications Ofcom: Children and parents: media use and attitudes report. Retrieved January 1, 2017. From https://www.ofcom.org.uk/ data/assets/pdf file/ 0034/93976/Children-Parents-Media-Use-AttitudesReport-2016.pdf, 2017.

53- National Sleep Foundation 2013 International Bedroom Poll First to Explore Sleep Differences among Six Countries. https://www.prnewswire.com/news/national-sleepfoundation. 
54- American Academy of Pediatrics, (2014). Retrieved July, 25, 2017.

55- LIVINGSTONE S.: The GSM Association and the Mobile Society Research Institute within NTT DOCOMO in Japan international comparison retrieved June 12, 2016, from www.gsma.com/publicpolicy/wp/content/uploads/ 2012/03/GSMA_ChildrensMobilePhones2012 WEB.pdf, 2013.

56- DRAGO E.: The Effect of Technology on Face-to-Face Communication The Elon Journal of Undergraduate Research in Communications, 6, 1. 13-19, from https://. www.elon.edu/docs/eweb/academics/communications/r esearch/vol6no1/02DragoEJSpring15.pdf, 2015.

57- DAI D. FRY A.: Effect of Video Games on Child Development Posted on https://my.vanderbilt.edu/ developmentalpsychologyblog/2014/04/effect-of-video-games-onchild-development/, 2014.

58- Entertainment Software Association: Essential Facts About the Computer and Video Game Industry. Retrieved from http://www.theesa.com/facts/pdfs/esa ef 2013.pdf, 2013.

59- ELMORE R.: The Effect Of Violent Video Game Play Onemotion Modulation of Startle Candidate for the Master of Arts Degreehttps://mospace.umsystem.edu/xmlui/ bitstream/handle/ 103 55 / 140 82/ElmoreEffVio Vi d.p df?s equ ence $=1 \mathrm{pdf}, 2012$.

60- Viacom Inc.: Annual Meeting of Stockholders and Proxy Statement to be filed with the Securities and ExchangeCommission pursuant to Regulation 14A of the Securities Exchange Act of 1934, as amended, are incorporated by reference into this Annualeport on Form 10-K (Portion of Item 5; Part III), 2014.

61- GINGOLD J.A., SIMON A.E. and SCHOENDORF K.C.: Excess screen time in US children: Association with family rules and alternative activities. Journal Clin. Pediatrics, 53 (1): 41-50. Retrieved April, 5, 2017. From doi: 10.1177/0009922813498152, 2014.

62- UNICEF: Child wellbeing in rich countries: A comparative overview. In: Innocent Report Card 11. Florence Italy: UNICEF Office of Research. Retrieved, June, 7. 2017. From https://www.unicef.org/media/files/ ChildPovertyReport.pdf, 2013.

63- Pew Internet and American Life Project: Teens, smartphones, and texting. Retrieved June 23, 2012 from http:// . www.pewinternet.org/Reports/2012/Teens-andsmartphones.aspx. 2012.

64- FOX and LEAH C.C.: "Effects of Technology on Literacy Skills and Motivation to Read and Write": Education and
Human Development Master's Theses. 522. http:// digitalcommons.brockport.edu/ehd theses/522, 2014.

65- DARAMOLA: On 10-15 years old in Finland to a study "Young Children as Internet Users and Parents Perspectives" http://jultika.oulu.fi/files/nbnfioulu- 201505261650. pdf, 2015.

66- BARNHORST C., WIJNHOVEN T.M., KUNESOV M. YNGVE A., RITO A.I., et al.: WHO European Childhood Obesity Surveillance Initiative: Associations between sleep duration, screen time and food consumption frequencies. Journal B.M.C. Public Health. Retrieved Apr. 30. 15: 442. From doi: 10.1186/s12889-015-1793-3.

67- BURKE J.: Why that smart phone might be bad for your health. Retrieved August 2, 2016, from http://www. . adn.com/voices/2016/05/22/why-that-smartphone-mightbe-bad-for-your-health/, 2016.

68- ZAFAR A.: Effects of chronic sleep loss in children and teens can be devastating. Retrieved July 10 , 2016. From http://www.cbc.ca/news/health/sleep-participaction1.3638191. 2016.

69- HARKINSON J.: The Long-Term Health Effects of Cell phones Children in particular may be vulnerable. Retrieved June 10, 2016, from http://www.motherjones.com/ environment/2015/05/cellphone-emf-wifi-health-risksscientists-letter, 2015.

70- FOLEY L.S., MADDISON R., JIANG Y., MARSH S., OLDS T. and RIDLEY K.: Pre sleep and Time of Sleep Onset in Children retrieved October 3, 2016, from http:// . pediatrics.aappublications.org/content/131/2/276, 2013.

71- PARRY S. and STRAKER L.: The contribution of office work to sedentary behavior associated risk BMC Public Health https://doi.org/10.1186/1471-2458-13-296, 2013.

72- EL-SHAFIE A.M., HOGRAN H.H. and DOHEIN A.M.: Prevalence of obesity in primary school children living in Alexandria governorate. Menoufia Medical Journal. Jun, 8, 2017. 29; 27: 529-32. From: http:// www.mmj. . eg.net/text.asp?2014/27/3/529/145502, 2014.

73- ARMENDAREZ J.: Video Game Use Among Children and Adolescents With Attention Deficit Hyperactivity Disorder" Open Access Master's Theses. Paper 768. From http://digitalcommons.uri.edu/theses/768, 2015.

74- GRABMEIER J.: National survey finds students optimistic, despite debt and stress. https://news.osu.edu/news/ 2015/07/01/financial-wellness/, 2015.

75- CURRIE E., et al.: High confidence proteomic analysis of yeast LDs identifies additional droplet proteins and reveals connections to dolichol synthesis and sterol acetylation. J. Lipid. Res., 55 (7): 1465-77, 2014. 


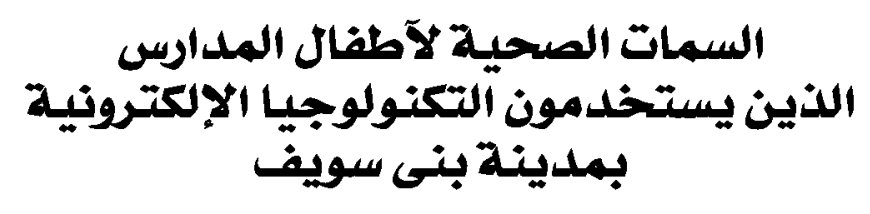

آخذت التكنولوجيا الإلكترونية آدوارا مركزية في الصياة اليومية للآطفال في المدارس الإبتدائية والإعدادية. اليوم، يمكن للآطفال الوصهل

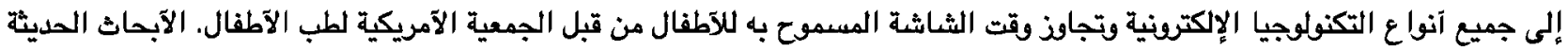

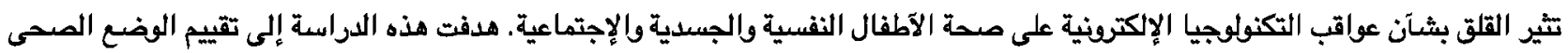

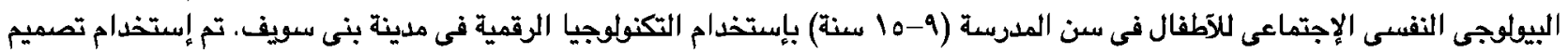

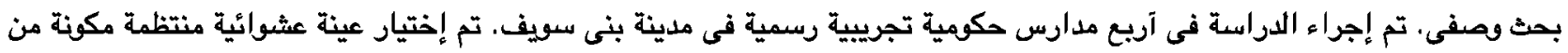

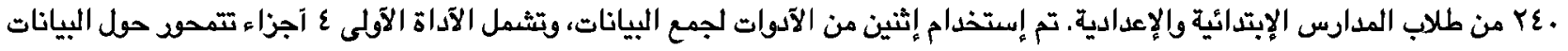

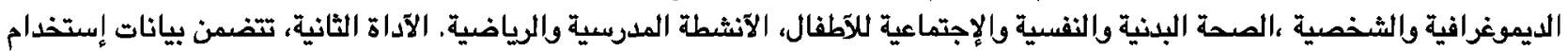

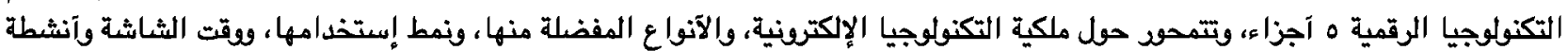

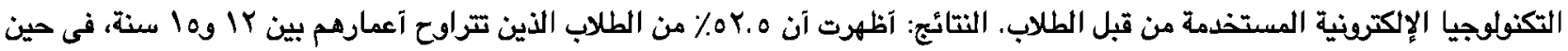

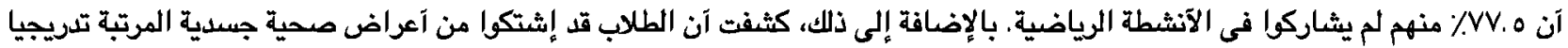

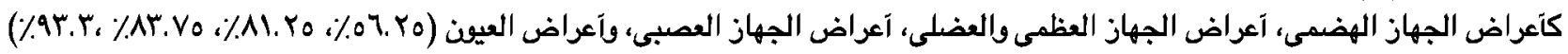

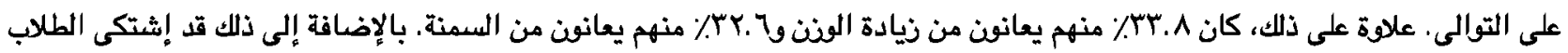

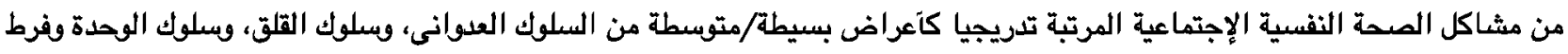

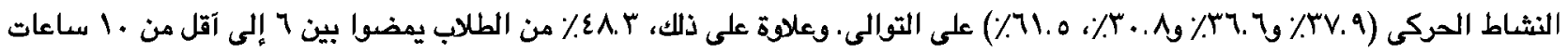

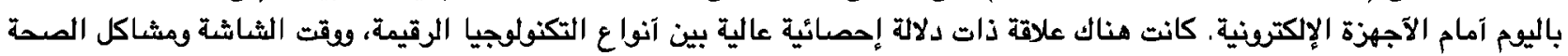

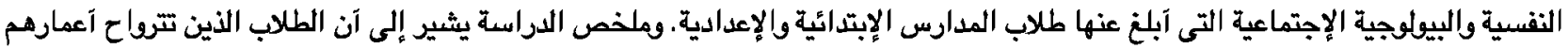

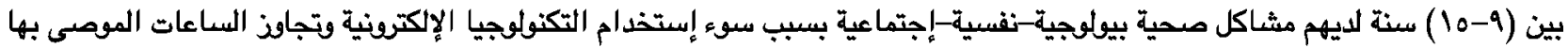

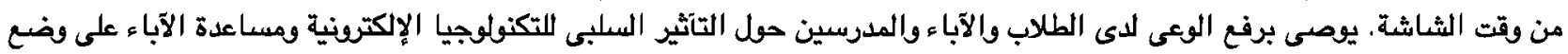
قواعد التحكم في وقت الشاشية ومحتوى التكنولوجيا الإلكترونية. 